\title{
INSTRUCTIES EN BESTUURSREGLEMENTEN NOPENS HET BELEID DER REGEERING TER KUSTE VAN GUINEE.
}

\section{1815.}

27 July 1815

$\mathrm{n}^{\circ} 31$.

Extract uit het Verbaal van den Staatsraad in buitengewonen dienst, belast met de portefeuille van het Departement van Koophandel en Koloniën. ${ }^{1}$ )

\section{Dingsdag $1^{\mathrm{e}}$ Augustus 1815.}

Gelezen hebbende een Besluit van Zijne Majesteit den Koning, genomen te Brussel den 27 July j.1. $\mathrm{n}^{\circ} 31$, van den navolgenden inhoud:

Wy, Willem, by de Gratie Gods Koning der Nederlanden, Prins van Oranje-Nassau, Groot-Hertog van Luxemburg enz. enz. enz.

Gezien hebbende de voordragt van onzen Staatsraad in buitengewonen dienst, belast met de portefeuille van Koophandel en Koloniën ${ }^{1}$ ), in dato 20 July $1815 \mathrm{n}^{\circ} 32 / \mathrm{B} 6$, opzigtelijk de maatregelen, die wegens de Nederlandsche etablissementen ter Kuste van Guinea behooren genomen te worden.

En hebbende geëxamineerd de instructie, voor den Hoofdgebieder te dier Custe ontworpen en ons door den Raad van Koophandel en lioloniën by desselfs rapport van 19 July 1815 aangeboden.

En na op die beide stukken te hebben gehad het advies van den Raad van State in dato 25 July $1815 \mathrm{n}^{\circ} 7$.

Hebben besloten en besluiten:

Art: 1.

De administratie der Nederlandsche etablissementen ter Kuste van Guinea zal, wat het personeel betreft, worden ingerigt, overeenkomstig de aan dit besluit sub A geanexeerde tabel. ${ }^{2}$ )

1) J. Goldberg.

2) Niet opgenomen.

D1. 86 . 
Art: 2 .

De thans fungerende Commandant-Generael de Veer wordt teruggeroepen, onder betuiging van ons genoegen over den standvastigen iever, welke hy in het waarnemen van dien post heeft aan den dag gelegd en behoudens de verpligting, hem by de volgende artikelen opgedragen.

Art: 3.

De residenten en verdere ter Kuste aanwezige geëmployeerden zullen, desverkiesende, permissie bekomen om te repatrieeren, of zoo zy hun verblijf en dienst in de kolonie wenschen te verlengen, in hunne tegenwoordige ambten of in anderen, volgens de nieuwe organisatie daarmede gelijkstaande, worden gebruikt.

Art: 4 .

Mr. H.W. Daendels wordt benoemd tot Gouverneur-Generaal der Nederlandsche Bezittingen ter Kuste van Guinea, op de aan deze sub litt. B geannexeerde instructie. ${ }^{1}$ )

Art: 5.

De Lieutenenant-Colonel Starrenburg wordt aangesteld tot Ingenieur ter meergemelde Kuste, onder verzekering dat hy, na een verblijf van drie jaren aldaar in onzen dienst doorgebragt, komende te repatrieeren, zal gesteld worden in het genot van het pensioen, waarop zijn rang bevonden worden zal hem aanspraak te geven.

Art: 6.

Ons zullen voordragten geschieden $1^{\circ}$ van de personen, welke het raadzaam zijn zoude naar de Kuste van Guinea uit te zenden, ten einde met de aldaar aanwezigen dienaren de posten te vervullen, by de tabel van organisatie omschreven. $2^{\circ}$ van den voet der uitzending, zoowel van dezelve personen, als van den Gouverneur-Generaal, waarbij in acht te nemen is, dat de voor d'Elmina in dienst gestelde corvet de Venus tot hun transport derwaarts behoort te worden gebruikt.

Art: 7.

De aftredende Commandant-Generael de Veer zal worden aangeschreven tot het doen der gemeenschappelijke inspectie, by de thans gearresteerde Instructie voor den Gouverneur-Generaal breeder omschreven.

1) Beneden, blz. 4 . 
Art: 8 .

Die inspectie zal echter nog in den loop van het tegenwoordige jaar moeten worden volbragt, zoodat de overgang van het gezag uiterlijk op den eersten January aanstaande plaats kunne hebben.

Art: 9.

Ter geregelde executie van hetgeene bepaald is by Art: 7 van de meergemelde instructie en speciaal tot kwyting van de zedert 1 December 1813 verdiende en verder tot ultimo December 1815 te verdienen gagiën, zullen aan den Commandant-Generaal de Veer worden toegezonden promessen, overeenkomstig het aan dezen geannexeerde model sub $\mathrm{C}^{1}$ ) en tot een bedrag, niet excederende de som van vijf en tachtig duizend guldens. Wel verstaande, dat de promessen niet zullen worden gebezigd tot liquidatic der tractementen, competerende aan die ambtenaren, welke, wanneer de Commandant-Generaal de hiertoe betrekkelyke aanschryving zal ontvangen, reeds mogten zijn overleden.

Art: 10 .

Aan den vertrekkenden Gouverneur-Generaal zal worden medegegeven eene som van vijf en dertig duizend guldens en zulks ten eincle door de gereede voldoening der militaire soldyen en kostgelden, gedurende het eerste jaar van deszelfs bestuur, een gepast crediet worde verzekerd aan de wisselbrieven op het Departement van Koophandel en Koloniën, met welke in het vervolg alle tractementen betaald zullen worden; en in de soldyen, kostgelden en het benoodigde voor de costumen en andere huishoudelyke onkosten zal worden voorzien.

Onze Staatsraad, belast met de portefeuille van Koophandel en Koloniën, is belast met de executie dezes, waarvan afschriften zullen worden gezonden aan den Raad van Staten en aan de Algemeene Rekenkamer.

Gegeven te Brussel, den 27 July des jaars 1815, het tweede van onze Regering, WILLEM.

Van wege den Koning,

A. R. FALCK.

Accordeert met deszelfs origineel.

De Griffier ter algemeene Staets Secretarie, S. DASSEVAEL.

1) Niet opgenomen. 
Heeft goedgevonden en verstaan 10 van den inhoud van het voorn: besluit van Zyne Majesteit by extract dezes kennis te geven aan den benoemden Gouverneur-Generaal Daendels, om denzelven te dienen voor acte van commissie en te strekken tot deszelfs informatie en narigt.

De Staatsraad voornoemd

J. GOLDBERG.

Instructie voor den Gouverneur-Generaal ter Kuste van Guinea.

Art: 1 .

De Gouverneur-Generaal, die van hier met een oorlogsvaartuig naar d'Elmina zal vertrekken, zal by zyne komst aldaar, alvorens het Gouvernement over te nemen, met den Commandant-Generaal de Veer en den hem, Gouverneur-Generaal, toe te voegen secretaris, zich dadelijk onledig houden met het inspecteren van alle de Nederlandsche établissementen en forten, alle 's lands gebouwen en eigendommen, fondsen en effecten, hoe oock genaamd, en onder welke afzonderlyke directie zich bevindende, en waar gelegen, de Lands slaven niet uitgezonderd, inventariseren, laatstgemelden op eene afzonderlyke inventaris, volgens het model L. A. nevens deze gevoegd, ${ }^{1}$ ) mitsgaders den staat der weeskamer en consignatiekas gedetailleerd opnemen en van al hetzelve proces-verbaal formeren en gezamentlijk teekenen.

Art: 2 .

Wegens derzelver bevinding zal door den Gouverneur-Generaal en den Commandant-Generaal een ampel rapport aan het Departement van Koophandel en Koloniën moeten opgemaakt worden.

Art: 3 .

Dadelijk nadat deze stukken zullen zijn geformeerd, hetwelk uiterlijk binnen acht dagen na de terugkomst op d'Elmina zal moeten plaatshebben, zal het Gouvernement door den Commandant-Generaal de Veer aan den Gouverneur-Generaal moeten worden overgedragen, en daarby een behoorlijk ceremonieel moeten worden in acht genomen.

Art: 4.

Zoodra de regering door den Gouverneur-Generaal zal zijn over-

1) Niet opgenomen. 
genomen, zal de gedefungeerd hebbende Commandant-Generaal zich moeten gereed maken, om binnen acht dagen daarna met 's lands vaartuig, waarmede de Gouverneur-Generaal is gearriveerd, te vertrekken, en zal dezelve met zich moeten nemen het ampel rapport, in Art : 2 gemeld, om hetzelve by zyne komst alhier, aan het Departement van Koophandel en Kolonien te overhandigen, tevens met een duplicaat van het proces-verbaal, Art: 1 voorkomende, blyvende een triplicaat van hetzelve proces-verbaal onder den Commandant-Generaal berusten.

Art: 5.

Dadelijk na de aanvaarding der Regering door den GouverneurGeneraal zal deselve, voor alle administratiën, nieuwe boeken doen aanleggen, en zorgen, dat alles, wat onder zijn bestuur voorvalt, daerin wordt te boek gesteld, wijl het 's Konings stellige wil en begeerte is, dat de nieuwe administratie met de oude op gecnerhande wijze wordt vermengd.

Art : 6.

Teneinde het bepaalde by het laatste gedeelte van het voorgaande artikel in deszelfs geheelen omvang zoude kunnen worden bewerkstelligd, zal door het Departement van Koophandel en Koloniën gezorgd worden, dat de Commandant de Veer van de noodige middelen worde voorzien, om de tractementen en soldyen der politieke ambtenaren en militaire officieren, welke voor den ouden dienst zullen loopen, van en met den eersten December 1813 tot en met den dag, dat het nieuwe Gouvernement aanvangt, af te betalen.

Art: 7 .

De Gouverneur-Generaal zal de opper-directie voeren over de Nederlandsche Etablissementen ter Kuste van Guinea, zoo in het militaire als in civiele, politieke en huishoudelijke, van wat aard en nature zulks ook zoude mogen zijn, en hij zal omtrent alles, wat den dienst in dezelfde Etablissementen betreft, alleen met het Departement van Koophandel en Koloniën corresponderen.

Art: 8 .

Hij zal zijne residentie houden te d'Elmina, met vrijheid echter, om na personeel onderzoek, ten nutte van de algemeene belangen, de residentie naar Chama of Axim te mogen verplaatsen.

Art: 9.

$\mathrm{H}: \mathrm{j}$ zal als het hoofd der krijgsmagt, zoo te water als te land, het 
oppercommando hebben over de militie, mitsgaders over alle schepen van oorlog, gedurende hun verblijf op de reede of kusten, zullende hij echter nooit eenige verandering in derzelver bepaalde destinatie mogen maken, dan op zyne personeele verantwoordelijkheid, behoudens dat eene expresse order van den Koning, of zijnentwege, omtrent de verdere destinatie van een zoodanig vaartuig, alle deliberatiën van den Gouverneur-Generaal deswegens dadelijk zullen doen cesseren.

\section{Art: 10 .}

Hij zal alleen responsabel zijn voor de verdediging der bezittingen, tegen alle aanvallen, zoo van buiten- als binnenlandsche vijanden.

Art: 11.

Hij zal niemand, uit de Nederlanden komende, aan 's Rijks établissementen admitteren, tenzij met een behoorlijke paspoort voorzien, en zal hij dezelve anderzints bij de eerste gelegenheid terug zenden, hun inmiddels onder behoorlijke surveillance houdende, en van den schipper, die zoodanige persoon heeft aangevoerd, doen vorderen eene boete van f 600 voor ieder persoon.

\section{Art: 12 .}

Hy zal aan niemand, van elders komende, (daaronder mede bếgrepen de koloniën en établissementen in de beide Indiën) toestaan, zich onder de forten neder te zetten, dan na behoorlijk onderzoek, en zal hy alle nieuw-aankomende, hetzij politieke of militaire ambtenaren of particuliere Europeërs, vrylieden of Tapoeyers, ${ }^{\mathbf{1}}$ ) binnen drie maanden (de militairen in tegenwoordigheid van een Hoofdofficier en de politicquen van een Raadslid en Secretaris) doen afleggen den eed van getrouwheid, invoege als bij het navolgend formulier :

„Wy beloven en zweren trouw aan Zyne Majesteit den Koning ,,der Nederlanden, alsmede eerbied en gehoorzaamheid aan de be,velen, welke van wegen Hoogstdenzelven zullen worden gegeven, ,als mede aan den Gouverneur-Generaal en andere publieke ,,ambtenaren”.

„Dat wy geen deel zullen hebben of nemen aan eenige zamen,scholingen, conspiratiën of factiën, maar dat wij daarentegen de ,algemeene rust en veiligheid en welvaard met alle onze vermogens ,bevorderen en alle schaden zullen helpen weeren, ons in alles

1) Afrikaansche soldaten. 
,onderwerpende aan de wetten en reglementen, gelijk zulks aan ,goede en getrouwe onderdanen, ingezetenen en militairen betaamt, ,zonder daarvan door vreeze voor lijf en goed, nochte door eeniger,hande andere oorzaken, in gebreke te blyven."

„Zoo waarlijk enz.”

Art: 13 .

Aan den Gouverneur-Generaal wordt de magt verleend, om aan blanken en mulatten of Tapoeyers, de inwoning binnen het territoir van Zijne Majesteit op de Kust te accorderen, ten einde aldaar handel te dryven en gronden te ontginnen, doch zal hij van deze toestemming of weigering t'elken drie maanden een specifique en gemotiveerde opgave, in den vorm van een tableau, aan het Departement van Koophandel en Koloniën inzenden.

Art: 14.

Hij zal den militairen arm niet alleen gebruiken tegen alle vijandelijke aanvallen van buiten, maar ook tegen alle oproerige bewegingen, welke zijn persoon en de belangen der verdere ingezetene in gevaar zouden kunnen stellen (waaronder echter niet kan verstaan worden de bevoegdheid, om eenige minder belangryke geschillen tusschen hem en de inlanders door de wapenen te doen beslissen); voorts zal hij dezelve bezigen tot bescherming en beveiliging van de goede in- en op-gezetenen en hunne bezittingen, tot maintien der orders, die hem door het Departement van Koophandel en Koloniën zullen worden gegeven, en eindelijk ter bescherming der Nederlandsche commercie en navigatiën, en om alle ongepermitteerde practijken en handelingen tegen te gaan en efficasieuselijk te beletten.

Art: 15.

Hij ziet zorgvuldig toe, dat de inlander wel en met menschlievendheid worde behandeld, en dat hem onder geen voorwendsel, hoe ook genaamd, eenige eetwaren, of wat het ook zoude mogen zijn, worde ontvreemd; dat niets beneden de waarde, of wel met andere goederen, dan de bedongen waren, worde betaald, mitsgaders dat de verdiende gagiën en daggelden aan hem niet worden onthouden.

Art: 16.

Zoo wanneer de établissementen ter Kuste met eenen vijandelijken aanval van buiten, of met eene geweldige beweging van binnen, gedreigd of wel dadelijk geattaqueerd of beroerd worden, of in andere zware of moeyelijke gevallen, zal hij eenen groote krijgsraad, be- 
staande uit de hoogste officieren, zoo te water als te lande, kunnen convoceren, bij welke hij ingevalle van binnenlandsche beroerte zal kunnen roepen zooveele politique ambtenaren, als hij zal goedvinden, beginnende echter altoos met den hoogsten rang, welke opiniën hij zal innemen, zonder nogthans verpligt te zijn, die te volgen, blijvende ieder gehouden zijne bevelen te obedieeren en te doen obedieeren.

Art: 17 .

Van de krijgsraden zal een afzonderlijk naauwkeurig verbaal gehouden worden, hetwelk bij de eerste gelegenheid aan het Departement van Koophandel en Koloniën zal gezonden worden.

Art: 18.

Niet alleen zal hij voor zich zelven trachten in goede harmonie en vaste vrede met de inboorlingen van het land te leven, maar ook, zooveel in zijn vermogen is, door minnelijke schikkingen helpen voor te komen de oorlogen, die tusschen dezelven mogten ontstaan, opdat de wegen niet onveilig zijn en daardoor de handel en correspondentie verhinderd worden.

Art: 19.

Hij zal zorgen dat alle de oude verdragen ${ }^{1}$ ) met de naburige Koningen of Natiën, ook die, bekend onder den naam van costumen, behoorlijk worden onderhouden, van alle dezelven eene specifieke opgave formerende, om die binnen zes maanden na zijn arrivement aan het Departement van Koophandel en Koloniën in te zenden.

Art: 20.

Zoo dikwijls zich daartoe de gelegenheid gunstig aanbiedt, sluit hij met de naburige Vorsten of volken nieuwe verdragen ${ }^{1}$ ) of contracten, mits gewijzigd naar de liberale grondbeginsels, volgens art. 60 dezer instructie, ${ }^{2}$ ) zorgende zooveel mogelijk, wanneer de aard der verdragen zulks vordert, om, tot betere verzekering van de naarkoming, gijzelaars te verkrijgen, verder in het oog houdende, dat door te maken bepalingen de Koningen worden verpligt, derzelver onderdanen bij voorkeur met de Nederlanders handel te doen drijven.

Bij de eerste scheepsgelegenheid zal de Gouverneur-Generaal aan het Departement van Koophandel en Koloniën van het sluiten van zoodanige nieuwe conventiën telken reize moeten kennis geven.

1) Zie: Tweede rapport der staatscommissie [-Baud] tot het voorstellen van maatregelen ten aanzien van de slaven..., 1856, blz. 70-80, 94-96, 321-322, $334-335,341-342$.

$\left.{ }^{2}\right)$ Lees: 59 en 60, inhoudende verbod van slavenhandel. 
Art: 21.

De Gouverneur-Generaal zal insgelijks met de naburige natiën kunnen contracteren tot het geven van adsistentie tegen hare vijanden, mits daartegen eenige belangrijke voordeelen voor het Rijk bedingende, en vooral in het oog houdende, dat zoodanige adsistentie nimmer kan worden ingeroepen tegen onderdanen van Europeesche geallieerde mogendheden. In zoodanige verdragen zal de GouverneurGeneraal byzonder letten, dat de alloude invloed van Nederland onder de inboorlingen van de Kust, bevestigd en uitgebreid worde.

Art: 22.

Hij presideert, of doet door andere beambten presideren de vergadering van de inlandsche hoofden bij de forten en kantoren, tot afdoening van klagten en geschillen, inbreuk op de contracten, en wat dies meer zij, doch welke geschillen, voor zooverre die de inboorlingen aangaan, niet anders dan volgens de voorouderlijke bestaande usantiën zullen beslist worden, van welke decisiën een behoorlijk verbaal zal moeten worden gehouden en om te dienen tot cen legger voor de volgende decisiën, welk verbaal alle drie maanden kopielijk zal moeten worden overgezonden aan het Departement van Koophandel en Koloniën, zullende echter noch hy, noch eenig ander van Zijne Majesteits beambten daarvoor van nu voortaan, noch directelijk, noch indirectelijk, iets aannemen, ontvangen, of genieten.

\section{Art: 23.}

Hij zal verantwoordelijk zijn, dat de goede harmonie met alle de Europeesche volken, die aan deze Kust komen, aldaar bezittingen hebben of handel drijven, worde onderhouden, en dat alle misverstand, zooveel immer mogelijk zij, worde voorgekomen, of uit den weg geruimd.

\section{Art: 24 .}

Hoezeer hij in alles het opperbestuur heeft, is hij desniettemin gehouden, in zaken van aangelegenheid den Grooten Raad te convoceren, welke zal bestaan uit alle de ambtenaren, tot den rang van eerste president ingesloten; in zaken van minder belang zal hij alleen raad houden met den contrarolleur van finantiën en der magazijnen, den inspecteur der gebouwen, forten en Gouvernements tuinen, en den secretaris en kassier; en bij absentie van een dezer drie, zal de in rang volgende ambtenaar daarbij adsisteren; en zal deze vergadering den naam van Kleinen Raad voeren; - hij zal zoowel in den Grooten, als Kleinen Raad, presideren en zorg dragen, dat de 
notulen van beide die vergaderingen in een appart verbaal worden ingeschreven, dat daarvan alle drie maanden een afschrift aan het Departement van Koophandel en Koloniën wordt ingezonden, en dat de besluiten der vergadering respectivelijk behoorlijk worden geëxecuteerd.

De deliberatiën dier vergaderingen zullen voornamelijk gaan over alle zaken, welke tot voordeel van den Nederlandschen koophandel, de landbouw en navigatiën zal kunnen verstrekken, en voor beide die raden zullen door hem instructiën worden geconcipieerd en ter approbatie des Konings aan het Departement van Koophandel en Koloniën worden ingezonden.

Art: 25.

Door den Gouverneur-Generaal zal een bekwaam persoon uit de respective ambtenaren onder nadere approbatie des Konings worden aangesteld als permanente vice-president, die tevens zal gehouden zijn de functiën van publiek aanklager waar te nemen; en voor zoo verre deze werkzaamheden daardoor te zeer worden vermenigvuldigd, zal hij van Gouvernementswege daarvoor behoorlijk worden gedefroyeerd; in de functie van vice-president werkzaam zijnde, zal hij onmiddelijk den rang op den Gouverneur-Generaal hebben en in dien van publieken anklager keert hij tot zijnen primitiven rang terug.

Art: 26.

Den Gouverneur-Generaal wordt aanbevolen om inzonderheid te waken, vooral wat eene goede politie vermag, ter bevordering van de gezondheid der onderhoorige ambtenaren en ingezetenen, en ter wering van alle besmettelijke ziekten, waartoe in aanmerking komt:

$1^{\circ}$ Of het niet raadzaam zijn zoude, om inplaats de ambtenaren in benauwde en weinig gemak hebbende vertrekken van het kasteel te doen wonen, gelijk tot hiertoe heeft plaats gehad, afzonderlijke woningen voor dezelven buiten de forten aan te leggen, hetzij bij wijze van casernen, of dorpsgewijze, met tusschenruimte ter doorlating van den luchtstroom, en met tuinen van moeskruiden voorzien; waartoe de kosten, vermits de bouwstoffen van hout, kalk en dakwerk van verschillend gewas bij de hand zyn, niet groot kunnen wezen.

$2^{\circ}$ In hoeverre het geraden zij, het aanleggen, indien zulks nog niet geschied mogte zijn, van een hospitaal, hetzij bij $\mathrm{S}^{t}$ Jago, of dieper landwaarts, of wel bij de bergen, met eenen bekwamen moestuin voorzien, om ook voor de schepelingen en tegelijk voor de nieuw 
aangekomen Europeeërs te kunnen dienen, om door eenig verblijf aldaar aan de luchtstreek te gewennen.

$3^{\circ}$ Het verbeteren van de gevangenhuizen, doende van alles prealabele en gedetailleerde berigten.

\section{Art: 27.}

Hem wordt insgelijks aanbevolen zorg te dragen voor de ongestoorde en regelmatige uitoefening van den Openbaren Godsdienst, zoodat bij indispositie van den Leeraar, de viering der Zondagen en verdere gewone kerktijden worde vervangen door het voorlezen in den Bijbel, en de gebeden geschieden volgens alloude gewoonte, zullende hij tot het bijwónen van den Openbaren Godsdienst alle geëmployeerden, zoo hoogere als lageren, welke zich ter Kuste of op de reede bevinden, voor zoo verre $\mathrm{zij}$ daartoe door geene wettige redenen verhinderd worden, aanzetten, en daarin zelfs met een goed voorbeeld voorgaen.

\section{Art: 28.}

Hij zal, zooveel in zijn vermogen is, het instituut tot onderwijs van de jeugd surveilleren en beschermen, in welk instituut de kinderen, zoowel der inboorlingen als der blanken, tot nuttige leden der maatschappij zullen kunnen worden opgeleid.

Ook zal hij, zooveel in zijn vermogen is, de zendelingen, welke ter onderwijzing en verkondiging van den Christelijken Godsdienst met voorkennis en goedkeuring van Zijne Majesteit aan de Kust arriveren, alle mogelijke hulp en adsistentie verleenen.

\section{Art : 29 .}

Hij zal niet vermogen eenige augmentatie van gagie aan een geëmployeerde toe te staan, de genoten wordende te verminderen, of eenige nieuwe ambten, ten laste van den lande, te creëren, wanneer hij daartoe niet speciaal geauthoriseerd is door het Departement van Koophandel en Koloniën.

Hij zal ook niet gedogen, dat door eenig geëmployeerde eigener authoriteit nieuwe emolumenten ingevoerd, of de reeds bestaande verhoogd worden.

\section{Art: 30 .}

Hij zal niet gedogen, dat een der geëmployeerden zich herwaarts begeve, om welke redenen, hoe oock genaamd, zonder zijn verlof te hebben gevraagd en bekomen, zullende zoodanig verlof altijd bepaald zijn op zes maanden, met injunctie aan den verzoeker, om dadelijk bij zijne aankomst in het Rijk daarvan kennis te geven aan 
het Departement van Koophandel en Koloniën, de approbatie op zijn verlof en, des begerende, prolongatie, van hetzelve te verzoeken.

Alle ambtenaren welke zich zonder zoodanig verlof van den Gouverneur-Generaal, of langer dan de aan hen geaccordeerden tijd, zonder wettige redenen en speciaale permisse van het Departement van Koophandel en Koloniën, absenteren, zullen van hunne ambten en bedieningen vervallen zijn.

Art: 31 .

Hij zal alle ambtenaren, welke hunnen tijd behoorlijk hebben uitgediend en in den dienst niet langer verkiezen te continueeren, voorzien van een dècharge en hen hunne demissiën accorderen, ten ware de noodzakelijkheid anders vereischte; doch zal hij ingeval van bekomen demissie een ieder hunner laten vertrekken, zooals zij best kunnen, buiten kosten van den lande, tenzij zulks te voren geaccordeerd was, als wanneer hij met deze lieden of met den schipper, die hen zal overvoeren, deswegens zal trachten te convenieeren.

Art: 32 .

Het gewoon verband voor een ambtenaar is vijf jaren, doch zullen die onder de thans fungeerende ambtenaren, welke alsnu opnieuw worden aangesteld, zich slechts telkens voor een jaar behoeven te verbinden.

\section{Art: 33 .}

Bij het overlijden van eenig ambtenaar, of eene bediening anderzins vacant rakende, zal de Gouverneur-Generaal daarvan bij de eerste gelegenheid aan het Departement van Koophandel en Koloniën kennis geven, met bijvoeging van zijn advies, of er ook aan de Kust zich geschikte sujetten tot vervulling derzelve bevinden, en die door hun gedrag bevordering meriteren; en zal hij tevens zorgen, dat de vacante bedieningen provisioneel en in afwagting van de dispositie van het Departement van Koophandel en Koloniën door bekwame personen, tegen genot van de daaraan geaccrocheerde appointementen en emolumenten, worden waargenomen.

\section{Art: 34 .}

De Gouverneur-Generaal zal de magt hebben tot het vervullen der plaats hebbende militaire vacatures, zoo ook om de demissiën van of ficieren aan te nemen en te verleenen, alles echter onder approbatie van het Departement van Koophandel en Koloniën.

Art: 35 .

Hij zal alle personen, onder hem gesteld, beëedigen, voor zooverre 
zij den eed niet hebben afgelegd voor het Departement van Koophandel en Koloniën, voorts hen houden tot een vlijtige en getrouwe waarneming hunner posten, en ingevalle zij zich mogten misgaan, hun volgens de wetten doen straffen.

\section{Art: 36 .}

Hij zal geene personen, die in eed en dienst van het Rijk staan, eigener authoriteit van hunne bedieningen mogen ontzetten of suspendeeren, tenzij de redenen, hem daartoe moverende, alvorens aan den Kleinen Raad te hebben gecommuniceerd, en die bij denzelven Raad, na het verhoor en de verdediging van den beschuldigden, zijn goedgekeurd; en zal van zoodanig feit bij de eerste gelegenheid aan het Departement van Koophandel en Koloniën volkomen informatie moeten worden overgezonden.

\section{Art: 37.}

Hij zal geen ambtenaar, hetzij militair, hetzij burgerlijk, uit hoofde van wangedrag naar de Nederlanden vermogen op te zenden (behalven in die gevallen, welke bij het volgende en bij articul 59 zijn omschreven), maar zorgen, dat dezelven naar de wetten, anderen ten voorbeelde, worden gestraft, hetzij met een confinement of op eenige andere wyze, doch nimmer met uitzetting of bannissement; en zal hij in geene vonnissen gedogen de woorden: prefercerende gratie voor rigueur van justitie.

\section{Art: 38 .}

De straffe des doods zal hij aldaar niet mogen infligeren, maar de zoodanigen, die beschouwd kunnen worden dezelve te hebben verdiend, herwaarts overzenden, benevens alle de stukken en interrogatoriën, daartoe betrekkelijk, teneinde hier te lande te worden te regt gesteld; wordende hiervan echter uitgesloten alle militairen, welke volgens bestaande krijgswetten aldaar zullen moeten worden gevonnisd en gestraft.

Art: 39.

De contrarolleur van finantiën zal tevens militair boekhouder wezen en het oppertoezicht hebben over alle magazijnen; aan hem zal de magazijnmeester zijn ondergeschikt.

Dezelve contrarolleur zal gehouden zijn, volgens de hem te geven speciale instructie, te werk te gaan en voor zoo verre den inhoud van hetzelve betreft, stiptelijk aan de nakoming derzelve gebonden zijn.

$$
\text { Art: } 40 \text {. }
$$

De Gouverneur-Generaal zal den contrarolleur van finantiën en 
der magazijnen, alsmede den cassier, op de meest efficasieuse wijze in de uitoefening hunner functiën ondersteunen, met dezelven overleggen al wat dienen kan tot het daarstellen van eene verstandige bezuiniging in de uitgaven en tot bevordering van 's Lands inkomsten, en wijders met hun nagaan, welke veranderingen in de instructiën der comptabele personen zouden behooren plaats te hebben, en daarvan, hetzij gezamentlijk, hetzij afzonderlijk, van tijd tot tijd aan het Departement van Koophandel en Koloniën een beredeneerd advies inzenden.

\section{Art: 41.}

Van de staten, welke door den contrarolleur van finantiën en door den cassier successivelijk aan hem, Gouverneur-Generaal, achtervolgens het bepaalde bij derzelver instructiën, zullen moeten worden overgelegd, zal hij van drie tot drie maanden afschriften aan het Departement van Koophandel en Koloniën moeten overzenden, voorzien van alle zoodanige observatiën en elucidatiën, als hij ten deze nuttig en noodzakelijk zal oordeelen.

Art: 42.

Ingevalle uit de staten mogt blijken dat er achterstallen te ontvangen waren, zal hij, Gouverneur-Generaal zorgen, dat de debiteur daarvoor worde aangesproken, en dat die gelden geïncasseerd worden; bij nalatigheid daarvan zal hij, beneffens den comptabelen, tot welkers functiën de invordering primitivelijk heeft behoord, en den contrarolleur van finantiën, voor de daardoor veroorzaakt wordende schade aansprakelijk zijn.

Art: 43.

Geen comptabele zal meer gelden onder zich mogen hebben dan het bedrag van deszelfs borgtocht; en zal het goud tot den koers, waarvoor hetzelve is ingenomen, als contant geld gerekend worden.

Ingevalle eenige comptabele meerder onder zich mogt hebben, zal, zoodra zulks uit de staten zal blijken, hetzelve worden gestort in eene afzonderlijke kist, aan welke zich zullen moeten bevinden drie onderscheidene werkende sloten, waarvan een in handen van den Gouverneur-Generaal, een in die van den contrarolleur van finantiën, en een in die van den cassier zal verblijven.

\section{Art: 44.}

Hij zal verpligt zijn binnen zes maanden na zijn arrivement aan de Kust, kopiën der provisioneele instructiën van de onderscheidene ambtenaren, met en benevens de overeenkomstig artikel 24 door hem 
te concipieeren instructie voor den Grooten en Kleinen Raad, aan het Departement van Koophandel en Koloniën in te zenden om 's Konings approbatie daarop te vernemen.

\section{Art: 45.}

Ten einde alle betalingen van tractementen en gagiën aan de militaire en civiele ambtenaren geregeld geschieden, zal de Gouverneur-Generaal daarvoor alle drie maanden wisselbrieven op het Departement van Koophandel en Koloniën voor de verschenen tractementen en gagiën afgeven.

$$
\text { Art: } 46 .
$$

Deze wisselbrieven zullen echter niet voor het totaal montant in massa kunnen getrokken worden, maar zal hij voor hetgeen ieder ambtenaar competeert, afzonderlijk een wissel in triplo aan deszelfs order moeten trekken, met vermelding in dezelve, over welk tijdvak hetzelve is verdiend, overeenkomstig het model daarvan, sub $\mathrm{L}^{\mathrm{a}} \mathrm{B},{ }^{1}$ ) bij deze instructie gevoegd, zullende het zoodanig ambtenaar vrijstaan met deze wissel naar welgevallen te handelen.

\section{Art: 47.}

Alvorens deze wisselbrieven aan dé respective ambtenaren worden gedistribueerd, zullen dezelve bij den contrarolleur van finantiën moeten geregistreerd en met zijne handteekening bekrachtigd worden.

\section{Art. 48.}

Van deze afgegevene wisselbrieven zal door den GouverneurGeneraal, bij eene specifique lijst, welke mede door den controlleur van finantiën zal moeten onderteekend zijn, volgens het hierbij gevoegd model, sub $\mathrm{L}^{\mathrm{a}} \mathrm{C},{ }^{1}$ ) dadelijk aan het Departement van Koophandel en Koloniën berigt moeten ingenomen worden.

\section{Art: 49.}

Behalven deze wisselbrieven zullen in geen geval zonder voorafgaande speciale authorisatie van het Departement van Koophandel en Koloniën, wisselbrieven op hetzelve door den Gouverneur-Generaal worden afgegeven.

\section{Art: 50 .}

Alle andere betalingen van soldij en kostgelden der militairen, vrije negers en slaven, zullen op de tot nu toe plaats gehad hebbende wijze in goud, à 40 guldens de once, geschieden.

1) Niet opgenomen. 
Art : 51.

De Gouverneur-Generaal zal ten gevolge der inspectie, in artikel 1 en 2 bevolen, zoo spoedig mogelijk een ampel berigt aan het Departement van Koophandel en Koloniën inzenden, bevattende eene gemotiveerde voordragt welke forten, établissementen en gebouwen, naar zijn oordeel, zullen behooren te worden aangehouden, welke uit hoofde van derzelver geringe nuttigheid zouden kunnen worden gemist, hoeveel de reparatiën van die, welke aangehouden moeten worden, zullen bedragen, welke de benoodigdheden zijn, daartoe in de magazijnen voorhanden, welke noodwendigheden aldaar voor die reparatiën kunnen worden aangeschaft en welke van hier daartoe zullen moeten worden uitgezonden; en zal hij daarbij byzonderlijk in consideratie moeten nemen de tegenwoordige omstandigheid van de Kust, in verband met het bij hem daaromtrent bekend systhema des Konings, den staat der finantiën van het Rijk, en de verpligting, om alle niet volstrekt noodzakelijke uitgaven te doen ophouden.

Tot zoo lange op deze voordragt $Z$. M. intentie aan hem niet zal zijn kennelijk geworden, zal door hem geenerhande reparatie mogen worden bewerkstelligd.

\section{Art: 52.}

Hij zal zich met zèle toeleggen op eene verstandige directie in het huishoudelijk en finantieel bestuur, onderzoeken in hoeverre het raadzaam zij de houtzagerijen, smederijen, kalkbranderijen en den canohandel voor rekening van het Gouvernement aan te houden (by dit laatste byzonderlijk in het oog te houden, dat het voordeel, hetwelk door den nu afgeschaften slavenhandel bevorens daaraan werd toegebracht, nu geheel wegvalt) en wel, of het raadzaam zij de houtzagerijen naar Chama of elders te verplaatsen en deswegens te dienen van een gemotiveerd rapport.

Art: 53.

Hij zal gehouden zijn stiptelijk te volgen de bevelen, welke hem door het Departement van Koophandel en Koloniën omtrent de inrigting zijner petities, het houden der boeken en verantwoordingen, de afrekeningen der ambtenaren, de liquidatie der boedelzaken van overledenen, de inrigting der magazijnen, met één woord, omtrent alle objecten, tot de huishoudelyke directie der Etablissementen beboorende, zullen gegeven worden, zijnde hij personeel verantwoordelijk voor de exacte executie der hiervoor gemelde bevelen. 
Art: 54.

Hij zal de nog in wezen zijnde slaven van het Gouvernement employeren tot den algemeenen dienst, overeenkomstig hunne capaciteiten en physique krachten; hij zal zorgvuldig waken dat de slaven op geenerlei wijzen worden mishandeld, hen desniettemin onder een strikte dicipline houdende, en zal hij niet gedogen, dat zij met meer rigueur worden behandeld, dan de algemeene individueele veiligheid vordert.

\section{Art: 55.}

Hij zal onverwijld, nadat hij zich genoegzaam bekend heeft gemaakt met de ligging der rivieren, de vruchtbaarheid der gronden en de dispositie der inboorlingen, om het plan van cultuur bevorderlijk te zijn, daarvan een omstandig verslag aan het Departement van Koophandel en Koloniën doen toekomen.

\section{Art: 56.}

Opzigtelijk de scheepvaart, het verlof tot het medegeven van dépèches aan schepen en al hetgeen den handel betreft, zal hij, Gouverneur-Generaal, zich reguleren naar de orders en reglementen, daaromtrent reeds gearresteerd of nog te arresteren. In het byzonder zal hy den Nederlandschen handel en de voortbrengselen van het land favoriseren, en van zijne consideratiën dienen omtrent alles, wat deswegens van nut zoude kunnen zijn.

\section{Art: 57.}

De handel en vaart op de bezittingen en etablissementen in Afica langs de Kust van Guinea, zal provisioneel vrij zijn van alle lasten, inzonderheid van alle inkomende en uitgaande regten; geene alteratie te dien opzigte zal plaats hebben, dan nadat alvorens door 's Konings besluit intijds daarvan kennis zal zijn gegeven, welk besluit eerst een jaar na de publicatie aldaar in werking zal worden gebracht.

\section{Art: 58.}

Hoewel het geenzins de intentie van den Koning is, eenige culture voor rekening van 's lands schatkist te entameren, wordt hem, Gouverneur-Generaal, niettemin ten sterksten aanbevolen, de belangen der ingezetenen te behartigen, ten einde door zijne tusschenkomst bij de onderscheidene Koningen of opperhoofden der verschillende natiën, zoodanige concessiën van landeryen te verkrijgen, voor hunne rekening en risico, welke meest geschikt zullen worden geoordeeld ter bereiking van hun oogmerk.

D1. 86. 
Art: 59.

Hij zal ernstig de hand houden aan de stipte inachtneming van het van den Koning geëmaneerd verbod van den overzeeschen slavenhandel, en bij afkondiging van hetzelve alle Nederlandsche onderdanen, ter Kuste woonachtig, kenbaar maken, dat zij zich door de minste overtreding te dien aanzien blootstellen om herwaarts ten hunnen koste te worden opgezonden, en zonder eenige oogluiking teregt gesteld.

Art: 60 .

Van het bedoelde verbod zal hij, dadelijk na zijne aankomst ter Kuste, insgelijks kennis geven aan de Koningin of opperhoofden der onderscheidene natiën, met uitnoodiging, om daarentegen hunne landgenooten tot het kweeken van suiker, koffie, katoen en andere voortbrengselen aan te moedigen, door welker ruiling voor Europische koopmanschappen het wederzijdsch gerief bevorderd wordt.

\section{Art: 61 .}

Met diezelfde bedoeling wordt hem en de hem onderhoorige ambtenaren en ingezetenen vrijgelaten om, voor hunne eigen rekening, eene proeve van zoodanigen cultuur te nemen en de inlanders alzoo bij ondervinding met de heilrijke gevolgen der industrie bekend te maken, zijnde het echter 's Konings intentie, dat bij die proeven hoofdzakelijk en bij voorkeur gebruik worde gemaakt van vrije werklieden, bij huur- of dagloon, en dat slechts bij gebreke van dezen en aanvankelijk, tot den dienst der slaven toevlucht genomen worde.

$$
\text { Art: } 62 \text {. }
$$

Op de billijke en menschlievende behandeling der aanwezige slaven, op het behoorlijk opvoeden der slavenkinderen en tegen het roekeloos door aankoop vermeerderen der slaven, zal de Gouverneur-Generael de meest doelmatige ordres stellen en successievelijck van het te dien aanzien verrigte rapport doen.

\section{Art: 63.}

Van alle nieuw te ontginnen landen zal niet dan ten einde van tien jaren beginnen geheven te worden eene jaarlijksche grondlast, ingaande met en over het elfde jaar, en welke grondlast alsdan nader zal worden bepaald.

\section{Art: 64 .}

De Gouverneur-Generaal zal alle besluiten, dépèches, orders en 
verdere documenten, welke hem in zijne qualiteit vanwege het Departement van Koophandel en Koloniën worden toegezonden, benevens de minuten der brieven en andere papieren, welke bij hem ontvangen worden, in de meest mogelijke order in gesepareerde quohieren conserveren, ten einde in geval van vacature alles aan zijnen opvolger zoodanig zoude kunnen worden overgegeven; zullende hij een behoorlijke gedresseerde inventaris van zijne chartres binnen den tijd van drie maanden, of zoo veel eer mogelijk, aen het Departement van Koophandel en Koloniën overzenden.

\section{Art: 65 .}

De Gouverneur-Generaal zal, in tijd van vrede, in de eerste drie maanden van ieder jaar, voor den dienst van het alsdan volgende jaar, en in tijd van oorlog, wanneer daartoe de gelegenheid voorhanden is, aan het Departement van Koophandel en Koloniën moeten inzenden staten van de militaire rantsoenen en benoodigdheden, tot het onderhoud der gebouwen enz., ter betaling, zoo der soldyen als van andere kosten van onderhoud, met bijvoeging, niet alleen van precise staten, van al hetgeen nog in de magazijnen ter Kuste voorhanden is, maar ook van kopyen der jongste voorgaande staten en gedetailleerde consideratiën over het gebruik, daarvan te maken. En zal hij bij het inzenden dier staten tevens moeten adviseren nopens de reparatiën en verbeteringen, welke aan de forten, magazijnen enz. zoude kunnen en behooren plaats te hebben; doch zal hij geen oude fortificatiën mogen doen slechten of nieuwe doen opwerpen, dan na voorafgaande bekomen authorisatie, welker aanvrage bij alle werken van aanbelang van een plan en van de raming der kosten moet vergezeld gaan.

\section{Art: 66.}

Hij zal regulier aan het Departement van Koophandel en Koloniën moeten toezenden behoorlijke, zoo door hem als door den contrarolleur van finantiën onderteekende, maandelijksche monsterrolle, met exacte aanteekening van de aangekomenen, overledenen en vertrokken personen, met designatie van den dag, waarop zij aangekomen, vertrokken of overleden zijn.

Art: 67.

Insgelijks zal hij regulier inzenden pertinente maandstaten van alle slaven, aan de établissementen behoorende, zoo als hij ook ter behoorlijker tijd zal doen formeren en aan het Departement van 
Koophandel en Koloniën inzenden, een specifique jaarstaat van alle dezelven, ingevolge de modellen sub $\mathrm{L}^{\mathrm{is}} \mathrm{D}$ en $\mathrm{E}$, nevens deze gevoegd, ${ }^{1}$ ) te formeren door den contrarolleur van finantiën en magazijnen en door hem, Gouverneur-Generaal, te viseren.

Art: 68 .

Hij zal een exact journaal houden van alle zijne ambtsverrigtingen en van al hetgeen, zoo te water als te lande, voorvalt, daarvan alle drie maanden aan het Departement van Koophandel en Koloniën inzendende een dubbeld of kopy, alsmede een dubbeld van alle rekeningen, mitsgaders van de boeken van den contrarolleur van finantiën, kassier, magazijnmeester, en van allen, die eenige administratie hebben.

Hij zal ook jaarlijks een generaal tableau doen formeren, bevattende de namen van alle in- en op-gezetenen, zoo ambtenaren, militairen als particulieren, de middelen van derzelver bestaan, en tot welke natie zy behooren, gelijk ook nog jaarlijks eene generale lijst van alle vaartuigen, in dat jaar aangekomen en afgevaren, met eene gedetailleerde opgave der ladingen, alsook van de plaatsen, vanwaar en waarheen zij gekomen en vertrokken zijn.

$$
\text { Art: } 69 .
$$

$\mathrm{Hij}$ zal niet gedogen, dat klagten van hemzelve tegen ambtenaren, of van ambtenaren onderling, in dépèches, aan het Departement van Koophandel en Koloniën geadresseerd, worden ingelast, maar zal daarvan eene byzondere remonstrantie moeten geschieden, gemunieerd met de noodige bewijzen, zullende anderszins alle onbewezen klagten worden geseponeerd en buiten dispositie gehouden.

Art: 70 .

Het is hem striktelijk verboden eenige monopolie te oefenen of in te voeren, eenige hindernis te weeg te brengen, of zich op eenigerlei wijze te verzetten tegen eenige geoorloofde handel van de ambtenaren, geëmployeerden of negotianten, maar hij zal daarentegen verpligt zijn zijne zaken zoodanig in te rigten, dat zij in zijnen handel zelven crediet en ondersteuning voor den hunnen vinden.

\section{Art: 71.}

Tot voorkoming van alle misbruik van eenig gezag van de zijde der publieke ambtenaren, is de Gouverneur-Generaal belast, geen

1) Niet opgenomen. 
hinder toe te brengen aan de vrijheid, welke alle onderdanen des Konings toekomt, om hunne belangen en klagten, zoo zij er eenige hebben, hetzij directelijk, hetzij door het Departement van Koophandel en Koloniën, ter kennisse van Zijne Majesteit te brengen.

Hij zal integendeel, waar het te pas komt, de verzekering geven, dat, gelijk van de eene zijde de wettige authoriteit der chefs en magistraten in de koloniën tegen alle atteinte zal gehandhaafd worden, en eene ongefundeerde klagt niet alleen niet geadmitteerd, maar zelfs de beschuldiger naar de gestrengheid der wetten gestraft, zoo ook aan den anderen kant de requesten en klagten, welke 's Konings onderdanen aan de Kust van Guinea vermeenen regt te hebben aan zijne Majesteit te doen toekomen, gunstiglijk aangenomen zullen worden.

\section{Art: 72 .}

De Gouverneur-Generaal zal in handen des Konings afleggen den navolgenden Eed:

„Ik zweere getrouwheid aan den Koning."

„Ik belove exactelijk te zullen nakomen de wetten, ordonantiën, ,reglementen en instructiën, welke mij in Hoogstdesselfs naam zul„len worden ter hand gesteld, te zullen gehoorzamen aan de bevelen „van het Departement van Koophandel en Koloniën, zoo die mij "reeds bekend zijn, als die mij in het vervolg zullen toekomen."

„Ik zweer de établissementen van het Rijk op de Westkust van „Africa te zullen besturen volgens de bestaande wetten, tot nut en ,voordeel van mijnen Souverein, en ten welzijn der ingezetenen, ,mijne instructie, zoo stiptelijck en getrouwelijck als in mijn ver„mogen is, te zullen nakomen, in mijne ambtsverrigtingen geen ,,ander doel dan het welzijn en den voorspoed van den Staat, en in ,het byzonder van het Gouvernement der kolonie, aan mijne zorg „toebetrouwd, te zullen hebben, de rigtige administratie der justitie ,te zullen handhaven en doen handhaven, de voornoemde établisse,"menten tot het uiterste te zullen verdedigen en $\mathrm{mij}$ te zullen ge,dragen gelijk het een goed en getrouw Gouverneur-Generaal ,betaamd."

Zoo waarlijk helpe mij God almagtig.

Art: 73.

Alle tot hiertoe bestaan hebbende reglementen, instructiën en usantiën, worden bij deze voor afgeschaft gehouden en buiten wer- 
king gesteld, voor zooverre dezelve aan den inhoud dezes zouden contrarieeren.

Aldus geapprobeerd bij 's Konings besluit van den 27 July 1815 $n^{\circ} 31$.

Mij bekend,

A. R. FALCK.

\section{1819. ${ }^{1}$ )}

1* November 1819

Wij, Willem, bij de gratie Gods Koning $\mathrm{n}^{\circ} 32$

der Nederlanden, Prins van Oranje-Nassau, Groot-Hertog van Luxemburg, enz. enz. enz.

Geëxamineerd hebbende enz.

Hebben besloten en besluiten.

Art: 1.

Behalve de hoofdplaats ter Kuste van Guinea, St. George a'Elmina, zal aan de bovenkust het fort St. Anthonie te Axim en aan de benedenkust het fort Crevecoeur te Accra, behoorlijk en in diervoege bezet blijven, dat er het Nederlandsch gezag, zoo binnenwaards als naar den zeekant, steeds kan worden gehandhaafd.

Art: 2.

De overige buitenforten zullen slechts in zooverre bezet worden, als nodig is voor de korrespondentie en om de vlag van afstand tot afstand te vertoonen.

Art: 3 .

Al deze buitenforten, zelfs dezulken, welke als ruïnen kunnen worden aangemerkt, blijven onder het bestuur van het Gouvernement ter Kuste.

\section{Art: 4.}

Op geen buitenforten zullen residenten worden geplaatst, dan te Axim en te Chama.

$$
\text { Art: } 5 .
$$

De titel van Gouverneur-Generaal ter Kuste van Guinea, wordt bij

1) Zie vooral artikel 12 hieronder, blz. 24 . 
dezen ingetrokken ${ }^{1}$ ) ; het hoofd der regering aldaar, welke zijn verblijf zal moeten houden te Elmina, zal den titel voeren van Kommandant.

Art: 6.

De huishouding ter Kuste zal voortaan ingerigt zijn op den voet, omschreven bij de tabel, aan dit besluit geannexeerd. ${ }^{2}$ )

Elk der geëmployeerden zal zooveel genieten, als daarop voor de door hem waargenomen bediening uitgetrokken is, en Onze voornoemde Minister zal zorg dragen, dat het beloop der overige kosten, waaromtrent de uitgetrokkene sommen slechts als ramingen worden beschouwd, nimmer te boven ga hetgeene, na voldoening der traktementen, disponibel blijven zal op de f 41.000 , welke jaarlijks ten behoeve van dit établissement kunnen worden besteed.

\section{Art: 7.}

Alle posten en bedieningen, thans nog in overeenkomst met ons besluit van den 4 September $1817 \mathrm{~L}^{n} \mathrm{X}^{2}, \mathrm{n}^{\circ} 62^{2}$ ) ter Kuste bestaand en welke niet bij de nu gearresteerde inrigting zijn vermeld, worden gehouden voor te zijn ingetrokken op den dag, dat het voormelde plan van organisatie zal zijn in werking gebragt.

Art: 8 .

De Gouvernementsslaven, zoo mannen, wijven als jongens, welke, boven de vijf en veertig manslaven, als soldaten dienstdoende, zich ter Kuste bevinden, met uitzondering echter van de gepensioneerde slaven, zullen tot verschillende werkzaamheden worden gebruikt, en de mannen ook in het byzonder als treingasten.

\section{Art: 9.}

De gepensioneerde slaven, zoo mannen en wijven als jongens, zullen dadelijk na het ontfangen van dit besluit worden vrijgegeven.

Art: 10 .

Tot de civiele posten, zooals dezelve bij de nieuwe inrigting voorkomen, worden bij dezen benoemd en aangesteld :

Tot Kommandeur :

De heer F. C. E. Oldenburgh, thans als president-provisioneel ter Kuste fungeerende;

1) Daendels (boven, blz. 2) was 2 Mei 1818 ovẹrleden.

2) Niet opgenomen. 
tot boekhouder, om te gelijck de functiën waar te nemen van secretaris, fiscaal en kassier, de heer M. Veenstra;

Tot residenten :

de heeren J. Ooshout en M. Cazillon;

tot adsistenten of klerken:

R. Roelofsen, W. Huydecoper, C. H. Bartels, C. G. Coorengel, F. Last en $H$. van der Breggen Pauw, de vier eersten met behoud van den thans door hen bekleden rang van tweede resident.

Tot fabrijk en magazijnmeester, te gelijk de functiën waarnemende van baas van den trein:

de heer $P$. Kelfken.

Tot chirurgijn-majoor, administrateur der medicijnen :

de heer S. F. Hueff, terwijl de post van chirurgijn zal blijven onvervuld, tot daartoe zich een geschikt persoon zal hebben opgedaan.

Art: 11 .

Ter vervulling van den post van militaire kommandant wordt bij deze benoemd en aangesteld, met den rang van tweede Luitenant, de sergeant Abraham van der Laan.

\section{Art: 12 .}

Bij alteratie van art : 24 der by Ons besluit van den $27^{\circ}$ July 1815 $n^{\circ} 31$ gearresteerde instructie ${ }^{1}$ ) voor den Gouverneur-Generaal ter Kuste van Guinea, welke instructie, voor zooveel dezelve door de bepaling van het tegenwoordig besluit niet komt te vervallen, in volle kragt blijft, en met vernietiging van de bij het voormelde 24 artikel voorkomende onderscheiding van Groten en Kleinen Raad, wordt het volgende vastgesteld:

A. De Raad ter Kuste van Guinea zal zijn tesamen gesteld uit den Kommandeur als president, den boekhouder als vice-president, de twee residenten, den chirurgijn-majoor.

B. Bij absentie van een of meerder der voormelde ambtenaren zullen de oudste adsistenten in rang, welke zich aan Elmina bevinden, derzelver plaats bekleeden.

C. Nimmer zal de militaire kommandant zitting in den Raad mogen hebben, doch in zaken, welke militair zijn, zal dezelve moeten worden gehoord, hetzij schriftelijk of mondelijk, nadat de Kommandeur zulks zal geraden oordeelen.

1) Boven, blz. 9. 
Art: 13 .

Ingeval een der ambtenaren, bij art. 10 en 11 van dit beshuit benoemd, voor die benoeming mogt bedanken, zal door den Kommandeur een ander uit de overige ambtenaren, onder Onze nadere approbatie, in desselfs plaats worden benoemd.

Art: 14 .

Ingeval echter de dienst zulks noodzakelijk mogt komen te vorderen, zal de Kommandeur vrijheid hebben om de demissie, hetzij van den door Ons benoemden ambtenaar, hetzij van dien, welke door hem wordt aangesteld, provisioneel niet aan te nemen, doch zal hij daarvan met opgave der redenen, bij eerste scheepsgelegenheid Onzen Minister voor het Publieke Onderwijs, de Nationale Nijverheid en de Koloniën, moeten kennis geven.

\section{Art: 15 .}

De ambtenaren, welke ten gevolge van dit besluit komen te vervallen, of die voor de aan hen aangeboden posten bedanken, en welker demissie aangenomen is, zullen bij eerste scheepsgelegenheid naer het Moederland vertrekken; op hen zal in dat geval van applicatie zijn het bepaalde bij Ons besluit van 26 September $1815 \mathrm{n}^{\circ} 13$, met betrekking tot de van de Kust repatrieerende ambtenaren, welke hunnen tijd hebben uitgediend, en zulks zoowel ten opzigte van de uitbetaling der traktementen, als van de transportgelden; zullende het kostende daarvan gevonden worden, ò [uit] hetgeen op den dienst van 1819, van de voor de kosten der etablissementen ter Kuste van Guinea geconsenteerde gelden zal bevonden worden over te zijn, òf uit zoodanige andere posten der begrooting, als door Ons zullen worden aangewezen. Onze Minister voor het Publieke Onderwijs, de Nationale Nijverheid en de Koloniën, is belast met de executie dezes, waarvan een extract, benevens kopy der tabel van de nieuwe inrigting, zal worden gezonden aan onze Minister van Financiën en de Algemeene Rekenkamer tot informatie.

Gegeven in 's-Gravenhage, den $1^{\mathrm{e}}$ November des jaars 1819, het zesde van onze Regeering.

WILLEM.

Van wege den Koning

J. G. DE MEY VAN STREEFKERK. 


\section{1838 .}

23 Maart 1838 $\mathrm{n}^{\circ} 104$.

Wij, Willem, bij de Gratie Gods Koning der Nederlanden, Prins van Oranje-Nassau, Groot-Hertog van Luxemburg enz. enz. enz.

Willende overgaan tot het daarstellen van eene nieuwe inrigting der administratie van onze Etablissementen ter Kuste van Guinea, ter vervanging van die, welke thans nog in werking is krachtens Ons besluit van den 1 November $1819 \mathrm{n}^{\circ} 32 .{ }^{1}$ )

Gezien de rapporten van Onzen Minister van Koloniën, ${ }^{2}$ ) de $d^{\circ} 13$ en 16 dezer $\mathrm{n}^{\text {os }} 152$ en 23.

Gezien het rapport van onzen Directeur-Generaal van Oorlog, de $\mathrm{d}^{\circ} 17$ dezer $\mathrm{L}^{\mathrm{n}} \mathrm{R}^{6}$.

Hebben besloten en besluiten:

Art: 1 .

De inrigting van het Gouvernement en de administratie onzer établissementen ter Kuste van Guinea wordt vastgesteld zoodanig, als dezelve in de, aan Ons tegenwoordig besluit gevoegde, tabel is omschreven. ${ }^{3}$ )

\section{Art: 2.}

In verband daarmede, worden benoemd en aangesteld:

tot Gouverneur met den titulairen rang van Luitenant-Kolonel: Hendrik Bosch, thans $2^{\text {de }}$ kapitein by de $4^{\circ}$ compagnie van het bataillon artillerie-transporttrein, met bepaling:

$a$. Dat zijne diensttijd ter Kuste aanvankelijk wordt vastgesteld op drie jaren.

$b$. dat aan hem na verloop daarvan zal worden toegestaan een jaarlijksch pensioen van twaalf honderd guldens (f 1200), te vermeerderen met twee honderd guldens (f 200) voor elk jaar langer dan drie jaren dienst ter Kuste voormeld.

c. dat, in het geval van overlijden gedurende zijnen dienst in Afrika aan zijne echtgenoote, vrouwe Maria Lohman, een buitengewoon jaarlijksch pensioen zal worden verleend van acht honderd guldens (f 800).

Tot Kommandant der gezwone militaire bezetting ter Kuste en

\footnotetext{
1) Boven, blz. 22.

2) J. van den Bosch.

3) Niet opgenomen.
} 
tevens Kommandant en Directeur van het Afrikaansche Werfdepot te St. George d'Elmina, met den effectiven rang van Kapitein, Dirk Stander, laatstelijk $1^{\mathbf{e}}$ Luitenant by de 9 afdeeling Infanterie, thans op non-aktiviteit, en zulks op het traktement der Indische Infanterie, aan zijnen effectieven rang verbonden, te voldoen uit de fondsen van het Afrikaansche Werfdepôt;

tot Eerste boekhouder, Fiskaal en Secretaris, met den titulairen rang van Kapitein: Christiaan Gerardus van Steenhoven Maarschalk, thans kommissaris van policie der stad Tilburg, en kapitein by het 2 bataillon der $1^{e}$ afdeeling mobiele Geldersche schutterij, met bepaling dat, ingeval van overlijden gedurende zijne diensten ter Kuste van Guinea, aan zijne echtgenoote, Johanna Louisa Vreeswijk en drie nog jonge kinderen, een jaarlijksch pensioen van acht honderd guldens (f 800 ) zal worden verleend, reversibel op de kinderen tot de jongste achttien jaren zal hebben bereikt;

tot Tweede boekhouder en ontvanger, tevens belast met de dienst als Intendant van Oorlog voor de Administratic van het Depôt der Afrikaansche werving te Elmina en elders, met den militairen rang van $1^{\mathrm{e}}$ Luitenant: J. C. Verhoef, wonende te Vlissingen, voormaals in onderscheidene militaire administratieve betrekkingen gediend hebbende;

tot Eerste resident, met den titulairen rang van Kapitein en het oud traktement ad twaalf honderd guldens (1200), mitsgaders loverigens op den voet als vroeger gebruikelijk was, ten aanzien van het drijven van handel: $A$. van der $E b$, thans resident ter Kuste en tijdelijk bevelhebber aldaar;

tot Tweede resident, met den titulairen rang van $1^{\mathrm{e}}$ Luitenant: N. B. Groen, thans ter Kuste aanwezig, met bepaling, dat hij, bij de hoofdadministratie geëmployeerd zijnde, zal genieten het tractement van duizend vijf honderd guldens ( $f$ 1500) jaarlyksch, doch op een der buitenforten gedetacheerd zijnde (met de bevoegdheid, om voor eigene rekening aldaar handel te drijven) op een traktement van zeven honderd vijftig gulden (f 750 )

tot Assistenten :

C. Ruhle.

Ch. Ruhle.

E. Pignari.

en $W . G . F . D e r x$.

De drie eerstgemelde respectivelijk thans ter Kuste dienende en 
de laatstgemelde woonachtig te Haarlem, en zulks met den titulairen rang van $2^{\text {de }}$ Luitenant en het jaarlijksch traktement van duizend guldens (f 1000), zoolang zij bij de hoofdadministratie werkzaam zullen zijn, doch op de buitenforten gedetacheerd zijnde (en als zoodanig bevoegd om voor eigen rekening handel te drijven) op vijfhonderd guldens (f 500) in het jaar;

tot surnumerair-assistent om bepaaldelijk belast te blijven met de functiën van Agent van het Nederlandsche Gouvernement te Coomassie en Directeur van het succursaal werfdepôt aldaar:

I. P. Huidecoper, thans met de voorschreven dienst belast, en zulks met den titulairen rang van $2^{\text {de }}$ Luitenant, en op een jaarlijksch tractement van negen honderd guldens (f 900) en eene toelage van honderd guldens (f 100) maandelijks, het een en ander betaalbaar uit de fondsen van het Afrikaansche werfdepôt te Elmina, zoolang deszelfs functiën te Coomassie zullen voortduren, en op het enkele traktement van duizend guldens (f 1000) by het eindigen daarvan en alsdan ter laste der koloniale kasse.

Art: 3 .

De vroeger bestaande verordeningen aangaande het verleenen van gratificatiën voor uitrusting en voorschotten op de respective tractementen aan zoodanige ambtenaren, welke naar de Kust van Guinea worden uitgezonden, zullen in werking blijven, zijnde drie maanden tractement voor gratificatie en gelijke drie maanden als voorschot.

Art: 4.

Onzen Minister van Koloniën wordt aanbevolen om te zorgen, dat in de dienstbrieven van alle de bij dezen bedoelde officieren en ambtenaren, uitdrukkelijk worde vermeld, ,dat van nu voortaan aan den „aangestelden, zoo hier te lande als aan de Kust van Guinea aan,wezig, de bevoegdheid wordt ontzegd om ter Kuste, hetzij voor ,eigen rekening, hetzij voor die van anderen, directelijk of indirec„telijk, handel te drijven, of zich met handelszaken, hoe ook genaamd, ,bemoeyenis te geven, in eenige andere aanraking buiten die, welke, ,ambtshalve gegeven, ons Gouvernement tot voorlichting zal kun,nen strekken ter bevordering van den Nederlandschen scheepvaart, ,industrie en handel in het algemeen, met uitzondering echter van het hiervoren bepaalde ten aanzien van de residenten en assistenten, op de buitenforten gedetacheerd zijnde, en van het[geen] personeel ten aanzien van den eersten resident $A$. van der $E b$ is bepaald. 
Art: 5.

De kosten, welke ten gevolge van de uitzending der drie voornoemde ambtenaren met namen:

$$
\begin{aligned}
& \text { C. G. van Steenhoven Maarschalk. } \\
& \text { J. C. Verhoef. } \\
& \text { en } W . \text { G. F. Derx. }
\end{aligned}
$$

naar de Kust van Guinea zullen voortvloeyen, zullen gevonden worden uit de voor die gewesten toegestane som van $\mathrm{f} 43.480$, bij de tabel, onder art. 1 vermeld, gespecificeerd.

En zullen afschriften dezes worden gezonden aan Onzen Minister van Koloniën, ter uitvoering, en aan Onzen Minister van Financiën, aan de Algemeene Rekenkamer, alsmede voor zooveel art. 2 betreft (en onder kopielijke mededeeling van het voorschreven advies en bylage van den 21 dezer, $n^{\circ}$. 165) aan Onzen Directeur-Generaal van Oorlog, tot informatie en narigt respectivelijk.

Gegeven te 's-Gravenhage, den 23 Maart des jaars 1838, het vijf en twintigste van onze Regering.

\section{WILLEM.}

Van wege den Koning:

VAN DOORN.

\section{1839.}

3 Maart 1839

$n^{\circ} .93$.
Wij, Willem, bij de Gratie Gods Koning der Nederlanden, Prins van Oranje-Nassau, Groot-Hartog van Luxemburg, enz. enz. enz.

Gezien het rapport van Onzen Minister van Koloniën ${ }^{1}$ ) van den 18 Februari 1.1., $\mathrm{n}^{\circ}$. 13, strekkende tot het daarstellen van eenige veranderingen in het bestuur en de administratie van Onze Etablissementen ter Kuste van Guinea, mitsgaders tot regeling, zoo van de uitgaven voor de Etablissementen, over 1839 aan te wenden, als yan

1) J. van den Bosch. 
de bezoldiging, gedurende dit dienstjaar, van een regter in het Gerechtshof tot wering van den slavenhandel te Sierra-Leone,

Gezien deszelfs nader rapport van den 28 der gemelde maand, $n^{\circ} .8$,

Gezien Onze besluiten de $\mathrm{d}^{\circ} .23$ Maart $1838, \mathrm{n}^{\circ} .104^{1}$ ) en 13 April $1838, n^{\circ} .72$,

Beschikkende tevens op het rapport van Onzen voornoemden Minister, van den 21 der vorige maand, $\mathrm{n}^{\circ}$. 15, omtrent de door den Gouverneur der bovengemelde Etablissementen gedane voorstellen tot het doen plaats hebben van reparatiën aan dezelve,

Hebben goedgevonden en verstaan:

$1^{\circ}$. de tabel der inrichtingen van het Gouvernement en de Administratie Onzer Etablissementen ter Kuste van Guinea, vastgesteld bij Ons voorschreve besluit van den 23 Maart 1838, n. 104, bij dezen in te trekken en buiten werking te stellen, met bepaling, dat dezelve wordt vervangen door de tabel, aan Ons tegenwoordig besluit gehecht ${ }^{2}$ ), wordende de hierboven aangehaalde rapporten de $\mathrm{d}^{\text {os }} .18$ en 28 Februari 1.1., $\mathrm{n}^{\circ}$. 13 en 8 gesteld in handen van Onzen Directeur-Generaal van Oorlog, ten einde Ons, nopens dit gedeelte derzelve, hetwelk de militaire rangen van de ambtenaren ter Kuste van Guinea betreft, te dienen van zijn consideratiën en advies.

$2^{\circ}$. Onzen voornoenden Minister te magtigen, om tot dekking der kosten voor de gemelde Etablissementen, alsmede tot voldoening van het traktement van een regter in het Gemengd Geregtshof te SierraLeone, tot wering van den slavenhandel, respectievelijk dienst 1839, over een gezamenlijk bedrag van zes en vijftig duizend, negen honderd tachtig guldens, uit de Oostindische fondsen te beschikken.

$3^{\circ}$. te bewilligen, dat uit die fondsen door Onzen meergenoemden Minister al verder beschikt worde over een som van zesduizend guldens, tot de bestrijding der kosten, welke zullen behooren te worden aangewend om de forten ter Kuste van Guinea, Batensteyn te Boutry en

Oranje te Nederlandsch Sacconde, in eenen bruikbaren staat te doen brengen.

En zijn Onze Minister van Koloniën, en, wat het slot van $\S 1$ aangaat, Onze Directeur-Generaal van Oorlog, belast met de uit-

1) Zie hiervóór, blz. 26.

2) Niet opgenomen. 
voering dezes, waarvan een afschrift zal gezonden worden aan Onzen Minister van Financiën, tot informatie.

's-Gravenhage, den 3 Maart 1839.

WILLEM.

Vanwege den Koning

VAN D()ORN.

\section{1847 .}

2 Julij 1847

$n^{\circ} .52$.
Reglement van bestuur voor de Nederlandsche bezittingen ter Kuste van Guinea.

Art: 1 .

Het hoogste gezag herust bij den Gouverneur. Een ieder is hein gehoorzaamheid en eerbied verschuldigd.

Art : 2 .

Aan den Gouverneur is toegevoegd een Kolonialen Raad, te zamen gesteld uit den boekhouder en of ficier van Justitie,

den hoofdingenieur der mijnen,

den oudsten in rang aanwezigen of ficier van het garnizoen,

en twee onbezoldigde leden, uit de ingezetenen te kiezen. De laatstgenoemden worden door den Gouverneur, onder nadere goedkeuring des Konings, benoemd, telkens voor den tijd van vijf jaren.

De Gouverneur is voorzitter.

Het lid, op hem in rang volgende, houdt nauwkeurig anteekeningen van de onderwerpen, in den Raad behandeld, van de geuite gevoelens, van de gronden, waarop zij rusten, en van den uitslag der stemming.

\section{Art: 3 .}

De Raad komt zoo dikwijls te zamen, als de Gouverneur dit noodig oordeelt, en beraadslaagt uitsluitend over de onderwerpen, door hem in deliberatie gebragt. De leden, voorstellen wenschende te 
doen, zullen die schriftelijk aan den Gouverneur mededeelen. Hem is het overgelaten om het voorstel al of niet in beraadslaging te brengen. In het laatste geval zendt hij hetzelve binnen de drie maanden aan het Departement van Koloniën, met opgave der redenen, waarom hetzelve door hem buiten overweging is gehouden.

Art: 4.

De Gouverneur is verpligt het gevoelen van den Raad in te winnen, zoo dikwerf er algemeene bepalingen uitgevaardigd, of belangrijke maatregelen genomen moeten worden. Hij alleen beslist. - Wanneer de Raad gehoord is, blijkt daarvan door de inlassching der woorden: "Gehoord den Kolonialen Raad", in de inleiding van het genomen besluit.

Art: 5 .

De Gouverneur is verantwoordelijk voor de door hem genomen besluiten, ook dan, wanneer dezelve overeenstemmen met het gevoelen van den Raad. Telkens, wanneer hij tegen het gevoelen der meerderheid beslist, vermeldt hij de redenen daarvan in zijn dagregister.

Art: 6.

Er wordt, in naam en van wege den Koning, regtgesproken door eene regtbank, die den naam voert van de Regtbank te St. George Delmina. Zij bestaat uit den Gouverneur, als voorzitter, en voorts uit den boekhouder en of ficier van Justitie, die tevens met de functiën van griffier belast is,

den hoofdingenieur der mijnen, oudst in rang aanwezigen resident,

oudsten in rang aanwezigen of ficier van het garnizoen,

en de beide ingezetenen, welke leden van den Kolonialen Raad zijn. Alle vonnissen van de Regtbank zullen de gronden moeten inhouden, waarop zij rusten.

De Gouverneur benoemt, uit de ambtenaren en ingezetenen, onder nadere goedkeuring des Konings, regters-plaatsvervangers, om op te treden, zoo dikwijls het vereischte getal leden ontbreekt.

In strafgedingen treedt de Officier van Justitie als openbaar aanklager op, en neemt geen deel aan de deliberatiën en aan de uitspraak.

$\mathrm{Hij}$ is belast met de uitvoering van alle strafvonnissen. Geen doodvonnis mag worden uitgevoerd zonder het "fiat executie" van den Gouverneur. 


\section{Art: 7 .}

De Regtbank te St. George Delmina doet uitspraak:

a. In het burgerlijke, met minstens drie regters, en zonder beroep, omtrent alle vorderingen, eene waarde van f 3000 niet te boven gaande. Wanneer de waarde in geschil meer dan f 3000 is, zal het hooger beroep aan den Hoogen Raad der Nederlanden zijn toegelaten, onverminderd de bevoegdheid van de Regtbank, om de voorloopige executie, met of zonder borgstelling, te bevelen.

$b$. In het criminele, met vijf regters, en in het hoogste ressort, behoudens dat de uitvoering der doodstraf, in afwachting van 's Konings beslissing, wordt geschorst, wanneer de veroordeelde aan Hoogstdezelve een verzoek doet om gratie; in welk geval dat verzoek met de processtukken wordt gezonden aan het Departement van Koloniën.

Alle zaken worden beslist bij volstrekte meerderheid van stemmen.

Art: 8 .

Ingeval een Europeaan of daarmede gelijk gestelde persoon veroordeeld wordt tot eene zwaardere straf dan gevangenzetting voor den tijd van twaalf maanden, zullen de processtukken gezonden worden aan het Departement van Koloniën.

Dat Departement zal die stukken telkens onderwerpen aan een opzettelijk onderzoek, ten einde zich te verzekeren, hoedanig de regtspraak wordt uitgeoefend, en of er aanleiding bestaat, om aan den Koning eenige voorziening voor te dragen.

Met Europeanen worden gelijk gesteld alle afstammelingen van dezelven, welke de Christelijke Godsclienst belijden, en als zoodanig in een door den Gouverneur aan te leggen register zijn ingeschreven.

\section{Art: 9.}

Ten aanzien van Europeanen en daarmede gelijk gestelde personen, regelt de Regtbank zich, zooveel doenlijk, naar de in Nederland bestaande wetten. Op de inboorlingen worden in het algemeen de landswetten en gebruiken toegepast, voor zoover zij niet tegen algemeen erkende beginselen van billijkheid en regtvalardigheid strijden.

In geen geval worden verminkende straffen opgelegd. De Gouverneur zorgt, dat binnen het jaar na de afkondiging van het tegenwoordig reglement, een compendium der landswetten en gebruiken worde vervaardigd, en aan het Departement van Koloniën gezonden.

D1. 86. 
Art: 10 .

De Gouverneur mag niet ter Kuste van Guinea geregtelijk aangesproken of in procedures betrokken worden ter zake van misdrijven, in of buiten zijn ambt gepleegd.

In burgerlijke zaken staat hij teregt voor de Regtbank te St. George Delmina..

Wanneer eene zaak voor de Regtbank wordt gebragt, waarin de voorzitter of een der leden is betrokken, onthoudt de betrokkene zich van alle deelneming aan de behandeling der zaak.

Art: 11 .

De militairen van het garnizoen zijn onderworpen aan de krijgswetten. Zij staan teregt voor de Regtbank te St. Gcorge Delmina, welke bevoegd wordt verklaard, om onder het voorbehoud, in art: 7 en 8 bepaald, in het hoogste ressort te beslissen.

\section{Art: 12 .}

Zonder uitdrukkelijken last des Konings mag tegen de inlandsche Vorsten of Volken geen oorlog worden aangevangen. Vijandige aanvallen worden echter met geweld te keer gegaan.

De Nederlandsche bezittingen worden in elk voorkomend geval tot het uiterste verdedigd.

\section{Art: 13 .}

De Gouverneur onderhoudt met de Gezagvoerders van anderc Europesche bezittingen ter Westkust van Afrika vriendschappelijke betrekkingen, en zorgt, dat alle aanleiding tot stoornis derzelver worde voorgekomen of uit den weg geruimd.

\section{Art : 14 .}

De overeenkomsten met de negerhoofden en stammen gesloten ${ }^{1}$ ), worden stiptelijk nageleefd.

De inboorlingen, onder het Nederlandsche gezag staande, worden met zachtheid en regtvaardigheid behandeld, en hunne instellingen en gebruiken geëerbiedigd.

Hun worden geene willekeurige lasten of diensten, door wien ook, opgelegd. Knevelarijen en afpersingen worden met nadruk geweerd.

Art: 15 .

De Gouverneur bevordert het schoolonderwijs, zooveel in zijn

1) Boven, blz. 8 . 
vermogen is. Hij zorgt, dat op Zon- en feestdagen Godsdienstige voorlezingen worden gehouden in het hoofdkasteel.

Art: 16.

De slavenhandel blijft ten strengste verboden op de straffen, bij de wet bepaald. De Gouverneur zorgt, dat aan schepen, van slavenhandel verdacht, geen kano's, noch roeyers (rimadores), noch eenige andere hulp van den wal verleend worde. Bijaldien zoodanige vaartuigen op de Nederlandsche ankerplaatsen aankomen, beveelt hij derzelver verwijdering.

\section{Art: 17 .}

De Gouverneur is gehouden om aan de officieren van vreemde mogendheden, met de wering van den slavenhandel belast, hulp en bijstand te verleenen. Hij laat, op het aanzoek dier officieren, het onderzoek van verdachte schepen op de Nederlandsche reeden toe, ten overstaan van eenen Nederlandschen ambtenaar, daartoe door hem aan te wijzen.

\section{Art: 18 .}

De Gouverneur bevordert den landbouw met de middelen, binnen zijn bereik liggende. Hij beschermt den handel, en moeligt inzonderheid de handelsbetrekkingen met Nederland aan. De handel is aan geene andere lasten onderworpen, dan die door den Koning zijn of nader zullen worden bepaald.

\section{Art: 19 .}

Geene ambtenaren mogen handel drijven, dan degenen, aan welke zulks uitdrukkelijk door den Koning is toegestaan. Zij onthouden zich, hunne persoonlijke belangen door de aanwending van hun ambtsgezag te ondersteunen. De Gouverneur is verantwoordelijk, dat ten deze geene misbruiken plaats hebben.

\section{Art: 20.}

Niemand mag zich in de Nederlandsche bezittingen op de Kust van Guinea metterwoon vestigen, zonder eene schriftelijke toelating van den Gouverneur. Die toelating wordt verstaan tot weder opzeggens toe te zijn verleend. Wanneer de Gouverneur de aan eenen Europeaan verleende vergunning intrekt, geeft hij daarvan kennis aan het Iepartement van Koloniën, onder mededeeling van de ter beoordeeling gevorderde stukken en omstandigheden. 


\section{Art: 21}

De Regtbank te St. George Delmina heeft het toezigt over de spoedige en regelmatige afdoening der boedels van ab intestato overledene Europeanen, en daarmede gelijkgestelde personen. Zoodanige nalatenschappen worden beheerd door minstens twee curatoren, door de Regtbank in elk geval te benoemen. De curatoren zorgen, dadelijk na hunne benoeming, dat de nalatenschap worde verzegeld en vervolgens geinventariseerd; dat de nagelaten goederen in het openbaar worden verkocht, en dat de boedel worde verevend. Zoo spoedig doenlijk zenden zij de rekening met de noodige bescheiden, en het batig saldo der nalatenschap, aan de Regtbank. Deze benoemt eene commissie van twee leden uit haar midden, om de rekening op te nemen, en daarvan rapport te doen. De rekening juist bevonden zijnde, wordt het saldo ten behoeve der regthebbenden gedeponeerd in 's lands kas, en worden de curatoren ontslagen.

Wanneer het in het belang der erfgenamen geoordeeld wordt de nagelaten goederen onverkocht te laten, dan wel die uit de hand te verkoopen, zal de Regtbank daartoe bevelen kunnen geven.

\section{Art: 22.}

Indien de erfgenamen zich niet op de Kust van Guinea bevinden, zendt de Gouverneur de boedelrekening met de bescheiden, benevens een wissel ten bedrage van het batig saldo, met de eerste gelegenheid aan het Departement van Koloniën, om door hetzelve aan de regthebbende te worden afgegeven. Ook dan, wanneer er geen batig saldo bestaat, wordt de rekening en bijlagen overgezonden ter uitreiking aan de nagelaten betrekkingen.

\section{Art: 23.}

De Gouverneur is voor het geldelijk beheer verantwoordelijk. Hij zorgt, dat alle rekeningen en boeken met duidelijkheid en eenvoudigheid ingerigt, en met nauwkeurigheid gehouden worden. Geen ambtenaar mag meer gelden of goederen onder zich hebben, dan voor de dagelijksche dienst worden vereischt. Het meerdere berust in de groote kas, of in het algemeen magazijn. De groote kas of geldkist moet voorzien zijn van drie verschillend werkende sloten. Een der sleutels berust onder den Gouverneur, en de beide anderen onder de twee oudste op hem in rang volgende ambtenaren, die hunne vaste standplaats te Elmina hebben. 


\section{Art: 24 .}

Tot betaling der administrative uitgaven, voor welke plaatselijk geene fondsen beschikbaar zijn, en welke mitsdien moeten worden gekweten uit het door den Koning toe te staan subsidie, geeft de Gouverneur driemaandelijks aan de belanghebbenden wissels in triplo op het Departement van Koloniën, betaalbaar te Amsterdam, drie maanden na zigt. Die wissels zijn voorzien van eenen stempel, en worden door den boekhouder geregistreerd en gecontrasigneerd.

\section{Art: 25 .}

De Gouverneur makkt eigenmagtig geene veranderingen hoegenaamd in de vastgestelde organisatie van het personeel der ambtenaren, en in het bedrag van derzelver tractementen en emolumenten.

$$
\text { Art: } 26 .
$$

Aan de ambtenaren en officieren kan, tot herstel van gezondheid of om andere dringende redenen, door den Gouverneur een verlof naar Nederland worden toegestaan, voor den tijd van zes maanden, onder genot van een door het Departement van Koloniën in elk geval te bepalen verloftractement.

\section{Art: 27.}

Aan de ambtenaren en officieren kan op hun verzoek en onder nadere goedkeuring des Konings, een voorloopig eervol ontslag uit hunne betrekking worden verleend. $\mathrm{Zij}$ mogen de Kust echter niet verlaten, alvorens behoorlijke verantwoording te hebben gerlaan van de door hen gevoerde administratie, waarvan de Gouverneur hun een bewijs uitreikt.

\section{Art: 28.}

De ambtenaren en officieren, die gedurende twaalf jaren met trouw en ijver ter Kuste van Guinea hebben gediend, en eervol zijn ontslagen, hebben regt op een door den Koning te bepalen pensioen. Aan weduwen en kinderen worden in geen geval pensioenen verleend.

\section{Art: 29.}

De Gouverneur is bevoegd, na den Kolonialen Raad te hebben gehoord, burgerlijke of militaire ambtenaren voor een bepaalden tijd in hunne bediening te schorsen. Wanneer hij vermeent, dat eenig ambtenaar uit de dienst behoort ontslagen te worden, zal hij, na voorloopige schorsing, den betrokken ambtenaar in de gelegenheid 
stellen, zich te verdedigen op de bezwaren, die tegen denzelven mogten zijn gemaakt. Hij zal de beschuldiging en de verdediging mededeelen aan den Kolonialen Raad en diens advies inwinnen. Bijaldien .hij bij het gevoelen volhardt, dat het ontslag van zoodanig ambtenaar behoort te volgen, zal hij de voordragt daartoe inzenden aan het Departement van Koloniën, met bijvoeging van alle tot de zaak betrekkelijke stukken.

Art: 30 .

De Gouverneur zendt jaarlijks, in de maand April, aan het Departement van Koloniën een kort verslag van den staat der forten en etablissementen, benevens een algemeenen inventaris van het aanwezig materieel en andere landsgoederen. Hij zendt bovendien telken drie maanden:

$1^{\circ}$. een afschrift van het door hem te houden dagregister, waarin zijne voornaamste handelingen moeten worden opgeteekend;

$2^{\circ}$. een afschrift van de notulen van het verhandelde in den Kolonialen Raad;

$3^{\circ}$. een afschrift der notulen van de Regtbank;

$4^{\circ}$. een advieslijst van de door hem getrokken wissels;

$5^{\circ}$. de monsterrollen van het burgerlijk en militair personeel, en van de arbeidslieden in 's lands dienst, met vermelding der mutatiën;

$6^{\circ}$. eene lijst van de aangekomen en vertrokken schepen, met vermelding van derzelver ladingen en van de plaatsen, vanwaar zij gekomen en werwaarts zij vertrokken zijn; en

$7^{\circ}$. eene lijst van de met die schepen aangekomen en vertrokken passagiers.

Art: 31 .

De Gouverneur zendt op den $1^{\text {n }}$ Augustus van elk jaar aan het Departement van Koloniën een overzigt van de in het afgeloopen jaar gedane ontvangsten en uitgaven, benevens eene raming derzelver voor het volgend jaar, opgemaakt 'volgens de deswege gegeven of nog te geven bevelen, alsmede eene aanvraag van uit Nederland te zenden benoodigdheden.

\section{Art: 32 .}

De Gouverneur doet voorts registers van den burgerlijken stand aanleggen, en, zooveel doenlijk, bijhouden, volgens daarvoor te geven voorschriften. 


\section{Art: 33 .}

Alvorens in functie te treden legt de Gouverneur den navolgenden eed af :

„Ik zweer, dat ik, om de bediening van Gouverneur ter Kuste van „Guinea te bekomen, aan niemand eenige geschenken of beloften „gedaan heb, noch doen zal ;"

,dat ik in de uitoefening dier betrekking den Koning gehouw en ,getrouw zal zijn”;

,dat ik den bloei en de welvaart van de bezittingen, ter Kuste voor,meld, zal voorstaan en behartigen, zonder aanzien van personen”; ,dat ik in de uitoefening mijner ambtspligten, zoo min aan be,dreigingen, als aan beloften, door wien ook gedaan, zal gehoor ,geven";

„,dat ik de algemeene en byzondere bevelen, mij door of vanwege ,den Koning te geven, getrouwelijk zal nakomen, en voorts alles „,zal doen, wat een goed en getrouw Gouverneur schuldig is en be,hoort te doen”.

,Zoo waarlijk helpe mij God Almagtig!”.

Wanneer de Gouverneur dezen eed niet in Nederland heeft afgelegd, doet hij dien in eene vergadering van den Kolonialen Raad.

In dit laatste geval wordt van de eedsaflegging procesverbaal opgemaakt, onderteekend, en aan het Departement van Koloniën gezonden.

De ambtenaren leggen bij de aanvaarding hunner betrekking den daartoe staanden eed, benevens dien van zuivering af, in handen van den Gouverneur.

\section{Art: 34 .}

Wanneer het ambt van Gotiverneur openvalt, zal het oudste in rang aanwezige lid van den Kolonialen Raad, volgens de rangschikking bij art: 2 bepaald, met den meesten spoed onderzoeken, of bij geheimen lastbrief vanwege den Koning een opvolger is benoemd.

Wanneer zoodanige lastbrief voorhanden is, zal dezelve in eene vergadering van den Kolonialen Raad worden geopend, en zal de daarbij benoemde persoon, na aflegging van den eed, de bediening van Gouverneur aanvaarden.

Geen lastbrief voorhanden zijnde, of bijaldien de aangewezen persoon afwezig is, zal het oudste lid van den Raad, na aflegging van den eed, de bediening van Gouverneur ad interim aanvaarden en het 
daaraan verbonden tractement genieten, totdat deswege door den Koning zal zijn beschikt.

Aldus goedgekeurd bij 's Konings besluit,' van den 2 July 1847 $n^{\circ} .52$.

Mij bekend,

De Minister van Koloniën,

J. C. BAUD.

\section{VI. $1848-1872$.}

Een bij de wet vastgesteld reglement op het beleid der regeering ter Kuste van Guinee, ingevolge artikel 59 der grondwet van 1848, is niet tot stand gebracht.

In 1864 schreef minister Fransen van de Putte aan de Tweede Kamer $\left.{ }^{1}\right)$ :

„Het kan betwijfeld worden, of de Nederlandsche vestiging ter Kuste van Guinea eene kolonie of territoriale bezitting in eigenlijken zin zij. Niettemin erkent de ondergeteekende, dat, zoolang ook voor haar geen regeringsreglement bij de wet is vastgesteld, aan art. 59 der Grondwet niet volledig zal voldaan zijn."

„Een aanvankelijk onderzoek heeft hem echter overtuigd, dat de moeilijkheden, aan de uitvoering verbonden, geene bepaalde toezegging hieromtrent voor het oogenblik veroorloven".

Op 10 Mei 1865 voegde de minister daaraan mondeling nog toe ${ }^{2}$ ):

„Wat een reglement voor de Kust van Guinea betreft, het is geene gemakkelijke taak zulk een reglement te ontwerpen, daar het eigenlijk onzeker is op welke wijze wij daar territoir bezitten".

De Kust ging aan Groot-Brittannië over op 6 April 1872. ${ }^{3}$ )

1) Bordewijk, Handelingen over de Reglementen op het beleid der Regering in de koloniën Suriname en Curaçao, 1914, blz. 806 (vergelijk blz. 803-804).

${ }^{2}$ ) Bordewijk, 1914, blz. 827 (vergelijk blz. 817 en 824).

3) Landvoogd waren na 1815 achtereenvolgens geweest:

Mr. H. W. Daendels . . . . . . . Gouverneur-Generaal 1816-1818

F. C. E. Oldenburg . . . . . . . Kommandeur 1818-1820

J. Oosthout . . . . . . . . . . President-kommandeur 1820-1821

F. F. L. U. Last . . . . . . . Kommandeur-ad intel im 1821-1822

L. J. Temmink . . . . . . . . . " " " 1822 
W. Poolman . . . . . . . . . . Kommandeur 1822-1823

H. A. Mouwe jr. . . . . . . . . Kommandeur-ad interim 1823-1824

J. D. K. Pagenstecher . . . . . . , ” , , 1824

F. F. L. U. Last . . . . . . . . " " $\quad$ "

J. C. van der Breggen-Pauw . . . " " " "

F. F. L. U. Last . . . . . . . . . Kommandeur 1827-1832

J. T. J. Cremer . . . . . . . . Kommandeur-ad interim 1832

E. D. L. van Ingen . . . . . . . " " "

M. Swarte . . . . . . . . . . . " " "

C. E. Lans . . . . . . . . . . . Kommandeur 1833-1836

H. J. Tonneboeyer . . . . . . Kommandeur-ad interim 1836-1837

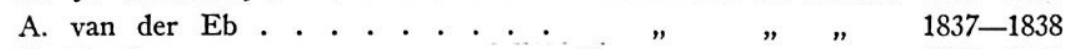

H. Bosch . . . . . . . . Gouverneur " $1838-1840$

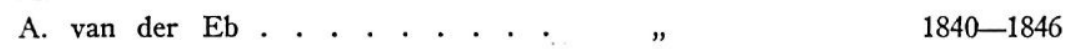

W. G. F. Derx . . . . . . . . Gouverneur-ad interim 1846-1847

A. van $\operatorname{der} \mathrm{Eb}$. . . . . . . . . Gouverneur 1847-1852

H. Schomerus. . . . . . . . . . ” 1852-1856

P. J. Runckel . . . . . . . . . Gouverneur-ad interim 1856

W. G. F. Derx . . . . . . . . . ” " " 1856-1857

J. F. R. S. van den Bosche . . . . . Gouverneur 1857

C. J. M. Nagtglas . . . . . . . Gouverneur-ad interim 1857

C. J. M. Nagtglas . . . . . . . . Gouverneur 1858-1862

H. A. Elias . . . . . . . . . . ” 1862-1864

C. H. D. van Hien . . . . . . . . Gouverneur-ad interim 1864

H. Doyer Hzn. . . . . . . . . . " " " 1864

H. A. Elias . . . . . . . . Gouverneur 1865

A. Magnin . . . . . . . . . Gouverneur-ad interim 1865-1866

W. H. J. van Idsinga . . . . . . Gouverneur 1866-1867

G. P. W. Boers . . . . . . . . . " 1867-1869

C. J. M. Nagtglas . . . . . . . . "

J. H. H. Hugenholtz . . . . . . . Gouverneur-ad interim 1871-1872 